\title{
Too much food may cause reduced growth of blue mussels (Mytilus edulis) - Test of hypothesis and new 'high Chl a BEG-model'
}

\author{
Larsen, Poul S.; Lüskow, Florian; Riisgård, Hans Ulrik
}

Published in:

Journal of Marine Systems

Link to article, DOI:

10.1016/j.jmarsys.2018.01.011

Publication date:

2018

Document Version

Peer reviewed version

Link back to DTU Orbit

Citation (APA):

Larsen, P. S., Lüskow, F., \& Riisgård, H. U. (2018). Too much food may cause reduced growth of blue mussels (Mytilus edulis) - Test of hypothesis and new 'high Chl a BEG-model'. Journal of Marine Systems, 180, 299-306. https://doi.org/10.1016/j.jmarsys.2018.01.011

\section{General rights}

Copyright and moral rights for the publications made accessible in the public portal are retained by the authors and/or other copyright owners and it is a condition of accessing publications that users recognise and abide by the legal requirements associated with these rights.

- Users may download and print one copy of any publication from the public portal for the purpose of private study or research.

- You may not further distribute the material or use it for any profit-making activity or commercial gain

- You may freely distribute the URL identifying the publication in the public portal 


\title{
Too much food may cause reduced growth of blue mussels (Mytilus edulis) - test of hypothesis and new 'high Chl $a$ BEG-model'
}

\author{
Poul S. Larsen ${ }^{1, *}$ Florian Lüskow ${ }^{2}$ and Hans Ulrik Riisgård ${ }^{2}$ \\ 1 DTU Mechanical Engineering, Fluid Mechanics, Technical University of Denmark, Building 403, DK-2800 Kgs. \\ Lyngby, Denmark \\ 2 Marine Biological Research Centre (University of Southern Denmark), Hindsholmvej 11, DK-5300 Kerteminde, \\ Denmark \\ * Correspondence: psl@mek.dtu.dk
}

\begin{abstract}
Growth of the blue mussel (Mytilus edulis) is closely related to the biomass of phytoplankton (expressed as concentration of chlorophyll $a$ ), but the effect of too much food in eutrophicated areas has so far been overlooked. The hypothesis addressed in the present study suggests that high chl $a$ concentrations (> about $8 \mu \mathrm{g} \mathrm{Chl} a \mathrm{l}^{-1}$ ) result in reduced growth because mussels are not evolutionarily adapted to utilize such high phytoplankton concentrations and to physiologically regulate the amount of ingested food in such a way that the growth rate remains high and constant. We first make a comparison of literature values for actually measured weight-specific growth rates $\left(\mu, \% \mathrm{~d}^{-1}\right)$ of small $(20-25 \mathrm{~mm}) M$. edulis, either grown in controlled laboratory experiments or in net bags in Danish waters, as a function of Chl $a$. A linear increase up to about $\mu=8.3 \% \mathrm{~d}^{-1}$ at $8.1 \mu \mathrm{g} \mathrm{Chl} a 1^{-1}$ fits the 'standard BEG-model' after which a marked decrease takes place, and this supports the hypothesis. A 'high Chl $a$ BEG-model', applicable to newly settled post-metamorphic and small juvenile (non-spawning) mussels in eutrophicated Danish and other temperate waters, is developed and tested, and new data from a case study in which the growth of mussels in net-bags was measured along a $\mathrm{Chl} a$ gradient are presented. Finally, we discuss the phenomenon of reduced growth of mussels in eutrophicated areas versus a possible impact of low salinity. It is concluded that it is difficult to separate the effect of salinity from the effect of $\mathrm{Chl} a$, but the present study shows that too much food may cause reduced growth of mussels in eutrophicated marine areas regardless of high or moderate salinity above about $10 \mathrm{psu}$.
\end{abstract}

Key words: bioenergetic growth model; chlorophyll $a$; salinity; weight-specific growth; eutrophication; Danish waters

\section{Introduction}

Filter feeding in Mytilus edulis is a secondary adaptation where the gills have become greatly enlarged to become mainly feeding structures that pump and filter water at rates evolutionarily adapted to the prevailing (low) concentration of phytoplankton in the sea (Jørgensen 1966, 1990, Famme \& Kofoed 1980, Jørgensen et al. 1986, Gosling 2015). Thus, the gills in mussels are much larger than needed for respiration. But the large gills are expensive to maintain and about $20 \%$ of the total metabolic output is used for maintaining the feeding structures, irrespective of whether or not the water-pumping lateral cilia are actively beating (Riisgård \& Larsen 1995). According to the hypothesis of 'minimal scaling' the energy cost for maintaining the structures of a filter-pump can only be justified when this part of the organism is minimally dimensioned, and for that reason continuously filtering the ambient water (Jørgensen 1975, 1990, Riisgård 2001). Because $M$. edulis is adapted to low phytoplankton concentrations it tends to be continuously filter-feeding at inherent rates when the food concentration is above a certain lower trigger level of about 0.5 to $0.9 \mu \mathrm{g} \mathrm{Chl} a 1^{-1}$ (Pascoe et al. 2009, Riisgård et al. 2011). Therefore, both the 'standard' BioEnergetic Growth model (BEG) (Riisgård et al. 2012) and the 'modified BEG-model' (Larsen et al. 2014, Larsen \& Riisgård 2016) are based on the presumption that M. edulis is continuously exploiting its filtration rate capacity when the Chl $a$ concentration is above the lower trigger level. Only in eutrophicated waters may phytoplankton levels reach concentrations above which $M$. 
edulis reduces its filtration rate by valve closing ('saturation reduction'). Thus, under optimal conditions, M. edulis tends to filter the ambient water at a maximum rate, but under sub-optimal conditions, including very low or very high phytoplankton concentrations, the filtration rate becomes reduced (Riisgård 2001, Riisgård et al. 2011).

Mussels save energy during starvation periods by partly closing their valves and thereby reducing the water transport through the mantle cavity so that the oxygen uptake and thus the metabolism is reduced, resulting in reduced body-weight loss (Famme 1980, Jørgensen et al. 1986, Riisgård \& Larsen 2015, Tang \& Riisgård 2016). The weight-specific growth rate of Mytilus edulis was found by Riisgård et al. (2013) to strongly decrease above the saturation level $\left(C_{\text {sat }}=\right.$ about 7.5 to $8.8 \mu \mathrm{g} \mathrm{Chl} a 1^{-1}$ ) clearly indicating that the growth potential was not being exploited. The reason is likely to be due to partial valve-closure and reduced oxygen uptake, because optimal growth seems to depend on unrestrained oxygen uptake, although production of pseudofaeces from the overloaded gills and excretion of undigested algae may also restrict the ability of $M$. edulis to grow (Riisgård et al. 2013). Thus, the phenomenon of reduced growth seems to be that M. edulis is not evolutionarily adapted to utilize (very) high phytoplankton concentrations and to physiologically regulate the amount of ingested food in such a way that the growth rate remains high and constant. Numerous growth rate measurements have over the years been made on M. edulis, and many environmental factors have been suggested to affect the actual growth, but the effect of too much food seems so far to have been overlooked as emphasised by Riisgård et al. (2013).

In laboratory experiments Riisgård et al. (2013) measured the filtration and growth rates of 22 to $35 \mathrm{~mm}$ shell length $M$. edulis at different algal concentrations maintained either below or above the limit of incipient saturation concentration $\left(C_{\mathrm{sat}} \approx 6,500\right.$ Rhodomonas salina cells ml ${ }^{-1}$, equivalent to about $8.1 \mu \mathrm{g} \mathrm{Chl} a 1^{-1}$, Clausen \& Riisgård 1996, which is in agreement with Riisgård et al. 2011, Fig. 5 therein). From a constant and high filtration rate $(F)$ measured below $C_{\text {sat }}$ the filtration rate decreased above $C_{\text {sat }}$ to about $10 \%$ of the former maximum value. Further, the measured weightspecific growth rates $(\mu)$ decreased sharply above $C_{\text {sat }}$ from a maximal value of about $9.5 \% \mathrm{~d}^{-1}$ to about $1.5 \% \mathrm{~d}^{-1}$ (Riisgård et al. 2013, Fig. 4 therein), but below $C_{\text {sat }}$ the $\mu$-values increased linearly with increasing algal concentration $(C)$ in good agreement with the 'standard BEG-model' presented by Riisgård et al. (2012, Eq.18 therein). The functional response of M. edulis described by Riisgård et al. (2013, Fig. 3 therein) resembled a Type I in terms of gross ingestion $(I=F \times C)$, but with rapid decrease instead of a constant maintained level above $C_{\text {sat }}$ in terms of net (or actual) ingestion (= gross ingestion - pseudofaeces). The physiological implications of this response are not obvious because it is only seen above $C_{\text {sat }}$ and then as reduced filtration rate along with production of pseudofaeces (Riisgård et al. 2011). As pointed out by Riisgård et al. (2013, Table 5 therein) the naturally occurring phytoplankton biomass (expressed as $\mathrm{Chl} a$ ) in coastal and open waters (excluding heavily eutrophic areas) is generally below $C_{\text {sat }}$ and therefore mussels tend to feed at optimal rates provided the $\mathrm{Chl} a$ concentration is above the lower trigger level where the mussels close their valves and reduce or cease filtering. In heavily eutrophicated marine areas the Chl $a$ concentrations may exceed $C_{\text {sat }}$ and the consequence of this for the growth of mussels seems so far to have been overlooked.

The hypothesis addressed in the present study suggests that high Chl $a$ concentrations ( $>$ about 8 $\mu \mathrm{g} \mathrm{Chl} a \mathrm{l}^{-1}$ ) result in reduced growth because mussels are not evolutionarily adapted to utilize such high phytoplankton concentrations. The value of about $8 \mu \mathrm{g} \mathrm{l^{-1 }}$ is the mean between 6 and $10 \mu \mathrm{g} 1^{-1}$, equivalent to the range 5,000-8,000 Rhodomonas cells $\mathrm{ml}^{-1}$ found in the controlled feeding experiments by Riisgård et al. (2011, Fig. 5 therein).

Here, we first (Section 2) compare with published values for actually measured weight-specific growth rates of blue mussels in field and laboratory exposed to various $\mathrm{Chl} a$ concentrations, including very high values as recently presented by e.g. Maar et al. (2015) and Landes et al. (2015) who correlated reduced growth with low salinity. Next (Section 3), we present a 'high Chl $a$ BEG- 
model' for mussel growth at extremely high Chl $a$ concentrations. Then (Section 4), we present a case study in which the growth of mussels has been measured along a $\mathrm{Chl} a$ gradient and finally (Section 5), we discuss the phenomenon of reduced growth of mussels in eutrophicated areas versus a possible impact of low salinity.

\section{Literature values of actual growth versus $\mathrm{Chl} a$ concentration}

Figure 1 shows the weight-specific growth rate of juvenile (20 to $25 \mathrm{~mm}$ shell length) Mytilus edulis as a function of $\mathrm{Chl} a$ measured in a number of studies conducted in temperate ( 8 to $20^{\circ} \mathrm{C}$, 8.5 to $29.9 \mathrm{psu})$ Danish waters or in controlled laboratory experiments $\left(10\right.$ to $\left.15^{\circ} \mathrm{C}\right)$. It can be seen that the linear increase up to about $\mu_{\max }=8.3 \% \mathrm{~d}^{-1}$ at $C_{\mathrm{sat}}=8.1 \mu \mathrm{g} \mathrm{Chl} a \mathrm{l}^{-1}$ fits the 'standard BEGmodel' after which a marked decrease takes place. However, in two cases where the mussels were fed algal cells in the laboratory they were also offered suspended inorganic particles (i.e. silt) and this resulted in even higher growth rates of 9.7 and $9.1 \% \mathrm{~d}^{-1}$ at 15.1 and $17.0 \mu \mathrm{g} \mathrm{Chl} a \mathrm{1}^{-1}$, respectively (Clausen \& Riisgård 1996, Table 4 therein). In general, the pattern supports the hypothesis that very high Chl $a$ concentrations ( $>$ about $8 \mu \mathrm{g} \mathrm{Chl} a \mathrm{l}^{-1}$ ) result in reduced growth and a 'high Chl $a$ BEG-model' for this phenomenon is presented in the next section. However, variations in salinity have also been suggested to be an important factor for reduced growth (e.g. Maar et al. 2015). This aspect is further treated in Section 5.

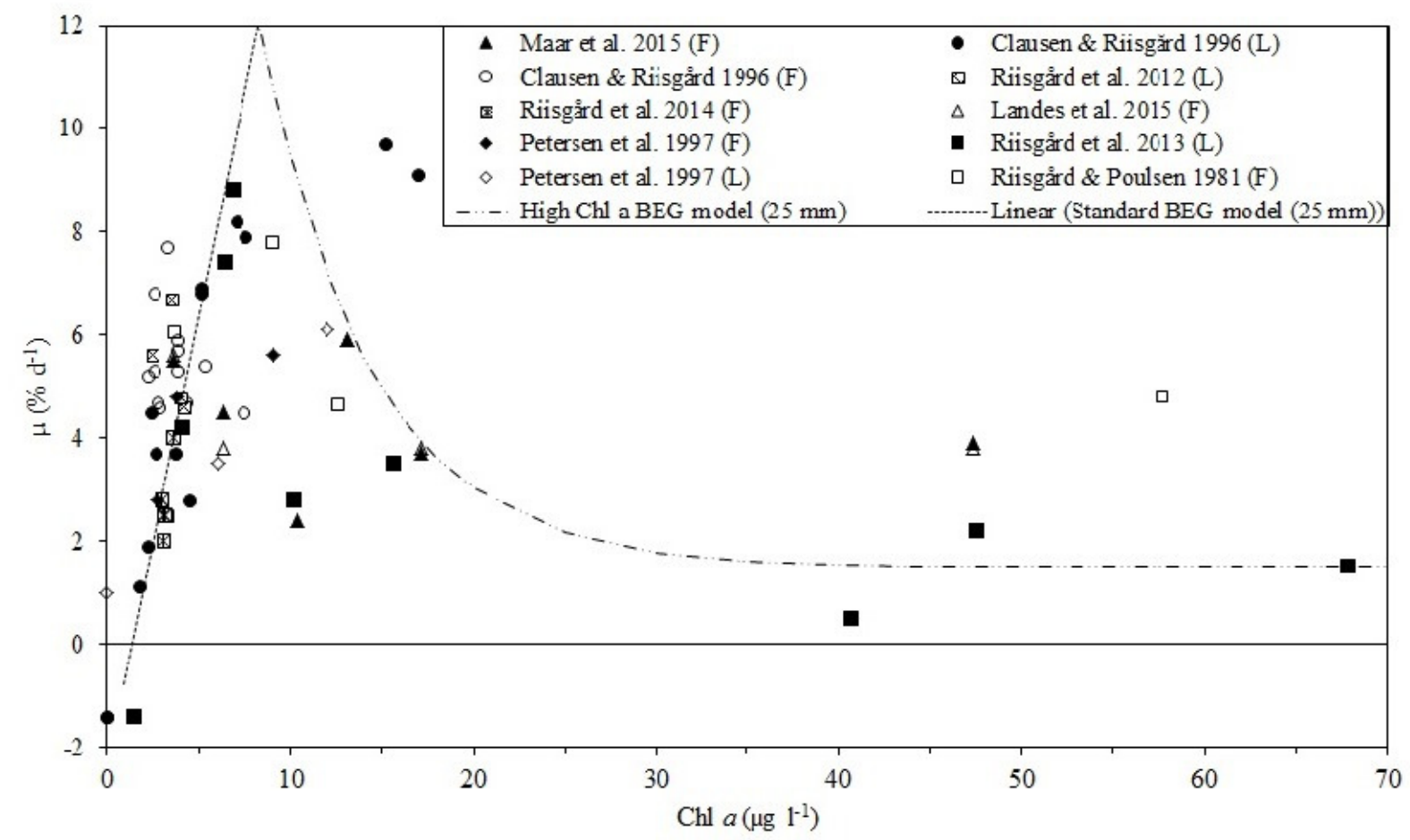

Figure 1. Mytilus edulis. Weight-specific growth rate as a function of chlorophyll $a(\mathrm{Chl} a)$ concentration obtained in a number of field (F) and laboratory (L) studies on small (20 to $25 \mathrm{~mm}$ shell length) mussels in the range of 8 to $20^{\circ} \mathrm{C}$. Predicted growth rate based on the 'standard BEGmodel' (Riisgård et al. 2012, Eq.18 therein) has been shown as a linear line for $25 \mathrm{~mm}$ mussels (other size classes are omitted for clarity), while the exponential decrease to a level of $\mu_{\infty} \approx 1.5 \% \mathrm{~d}^{-}$ ${ }^{1}$ for $C>C_{\text {sat }}$ is given by the 'high Chl $a$ BEG-model' expressed by Eqs.(4) and (5) for the case of shell length $25 \mathrm{~mm}$. 


\section{3. 'High Chl $a$ BEG-model'}

\subsection{Model development}

The 'modified BEG-model' (Larsen et al. 2014, Eq.5 therein) is given by

where

$$
(\mathrm{d} W / \mathrm{d} t)_{\bmod }\left(\mathrm{mg} \mathrm{d}^{-1}\right)=c_{1} W(\mathrm{mg})^{0.66}, \mathrm{C}<C_{\text {sat }},
$$

$$
c_{1}=0.1047 \times m_{1} \times\left(0.871 \times m_{2} \times n_{2} \times C \times A E / 0.80-0.986 \times m_{3} \times n_{3}\right) .
$$

Table 1. Coefficients in Eq.(2)

\begin{tabular}{l}
\hline$m_{1}=1.12 /\left[1+\left(a_{0}-1\right) n_{3}(1-E)\right]$ \\
$m_{2}=1-E ; a_{0}=1.12$ \\
$m_{3}=1-0.9\left(1+C / C_{0}\right) E$ \\
$E=\exp \left(-C / C_{0}\right)$ \\
$C_{0}=0.4 \mu \mathrm{g} \mathrm{Chl} a 1^{-1}$ \\
$n_{2}=\left[1+0.0251\left(T-T_{\mathrm{F}}\right)\right]$ \\
$n_{3}=1.54^{(T-T Q) / 10}$ \\
$T_{\mathrm{F}}=11.5{ }^{\circ} \mathrm{C} ; T_{\mathrm{Q}}=14{ }^{\circ} \mathrm{C}$ \\
\hline
\end{tabular}

Coefficients $m_{1}, m_{2}, m_{3}, n_{2}$, and $n_{3}$, listed in Table 1, account for reduced filtration rate at low values of $C\left(<1 \mu \mathrm{g} \mathrm{Chl} a \mathrm{l}^{-1}\right)$ and the temperature dependence of filtration rate and respiration above about $8{ }^{\circ} \mathrm{C}$. When these coefficients are equal to 1.0 Eqs.(1) and (2) reduce to the 'standard BEG-model', or in terms of $\mu\left(\% \mathrm{~d}^{-1}\right)=W^{-1} \mathrm{~d} W / \mathrm{d} t$, to (Riisgård et al. 2012, Eq.18 therein)

$$
\mu_{\mathrm{Std}}=(0.871 \times C \times A E / 0.80-0.986) W^{0.34},
$$

which for a given $W(\mathrm{~g})$ suggest the linear increase of $\mu$ with increasing $C<C_{\text {sat }}$ as shown by data in Fig. 1. However, above $C_{\text {sat }}\left(=8.1 \mu \mathrm{g} \mathrm{Chl} a 1^{-1} \approx 6,500\right.$ Rhodomonas salina cells $\left.\mathrm{ml}^{-1}\right)$ the data suggest an exponential (or hyperbolic) decrease of $\mu$ with increasing $C$ to a low level of about $\mu_{\infty} \approx$ $1.5 \% \mathrm{~d}^{-1}$. More detailed data (Riisgård et al. 2013, Fig. 3 therein) show a similar decrease of the filtration rate $F$ with increasing $C$ while the gross ingestion rate $I=F \times C$ remains nearly constant which confirms consistently the trends. Since the two terms in the bracket of Eq.(3) represent assimilated food $(A)$ and respiration, respectively, it is concluded the assimilation efficiency $A E=$ $A / I$ must decrease with increasing $C$ above $C_{\text {sat }}$ which in turn appears to be consistent with the observed increasing production of pseudofaeces. This suggests a 'high Chl $a$ BEG-model' for C > $C_{\text {sat }}$ of the form

$$
\mu_{\mathrm{Hi}-\mathrm{Chl}}=\left(0.871 \times m_{4}-0.986\right) W^{0.34},
$$

or in terms of form and units of Eq.(1),

$$
(\mathrm{d} W / \mathrm{d} t)_{\mathrm{Hi}-\mathrm{Chl}}\left(\mathrm{mg} \mathrm{d}^{-1}\right)=0.1047 \times\left(0.871 \times m_{4}-0.986\right) W(\mathrm{mg})^{0.66}, \mathrm{C}>C_{\text {sat }},
$$

where

$$
m_{4}(=C \times A E / 0.80)=C_{\text {sat }} E+C_{\infty}(1-E) ; \quad E=\exp \left[-\left(C-C_{\text {sat }}\right) / C_{\text {ref }}\right] .
$$

Here, constants are determined to approximately match data at saturation of Fig. 1 to Eq.(3) such that $C_{\text {sat }}=8.1 \mu \mathrm{g} \mathrm{Chl} a 1^{-1}$ for mussels of shell length $L=25 \mathrm{~mm}$ corresponding to $W(\mathrm{~g})=2.15 \times 10^{-6}$ 
$L(\mathrm{~mm})^{3.40}=0.122 \mathrm{~g}$ (according to Larsen et al. 2013, Fig. 8 therein), which gives $\mu_{\text {sat }} \approx 12 \% \mathrm{~d}^{-1}$. Constants for filtration and respiration rates are kept at their standard values to ensure match of models at $C=C_{\text {sat. }}$. Finally, to match the asymptotic value $\mu_{\infty} \approx 1.5 \% \mathrm{~d}^{-1}$ for large values of $C$, Eqs.(4) and (6) give $C_{\infty}=1.97$ for decay constant $C_{\text {ref }}=6$. Using these values in Eq.(4) gives the curve for $C>C_{\text {sat }}$ in Fig. 1. Furthermore the model so far has been derived from models applicable to juvenile mussels of shell length $>$ about $10 \mathrm{~mm}$, corresponding to dry weight $>$ about $10 \mathrm{mg}$, and tests may include mussel growth starting from newly settled post-metamorphic state. We therefore consider also the ad hoc BEG model (Larsen \& Riisgård 2016, Eq. 11 therein) valid for $W<10.25$ mg,

$$
(\mathrm{d} W / \mathrm{d} t)_{a d ~ h o c}\left(\mathrm{mg} \mathrm{d}^{-1}\right)=0.0218 \times(4.89 \times C \times A E / 0.80-5.54) W(\mathrm{mg})^{0.887}, C<C_{\max },
$$

and, following the idea leading from Eq.(3) to (4), we propose to replace $C \times A E / 0.80$ of Eq.(7) by $m_{4}$ of Eq.(6) to obtain

$$
(\mathrm{d} W / \mathrm{d} t)_{a d} h o c\left(\mathrm{mg} \mathrm{d}^{-1}\right)=0.0218 \times\left(4.89 \times m_{4}-5.54\right) W(\mathrm{mg})^{0.887}, C>C_{\max } .
$$

It remains to account for possible seasonal events of no growth (or negative growth due to starvation) during winter periods at low temperature. This may depend on location. Seasonal cycles of dry weight of soft tissue of Mytilus edulis in Wales, UK was studied by Dare \& Edwards (1975) and Dare (1976). For juveniles (30 to $35 \mathrm{~mm}$ shell length), involving no gametogenesis, dry weight started increasing at the end of winter in February (Dare 1976, Fig. 15 therein). But for Danish waters, experience shows that the period of no growth typically occurs from early October to March or April before the spring bloom. Thus, data from the Great Belt, Denmark (Larsen et al. 2013, Table 2 and Fig. 2 therein) show net negative growth $\left(\mu=-0.3 \% \mathrm{~d}^{-1}\right)$ from 4 October to 9 December of 2010 and spring bloom during the month of March 2011. Data from Skive Fjord, Denmark by Nielsen et al. (2016, Table 1 therein) show a similar net negative growth $(\mu=-0.23 \%$ $\mathrm{d}^{-1}$ ) from 28-Oct-10 to 16-Mar-11. It is therefore proposed to include into the model for Danish waters a 'winter-limiter' of no growth during the period 1 October 2010 to 15 March 2011.

\subsection{Growth prediction}

The model has been tested against the growth data from Nielsen et al. (2016, Table 1 therein, in which the first value of dry weight $(0.002 \mathrm{~g})$ was later provided by the authors) shown as Table 2 , where we have added values of weight-specific growth rate from $\mu=\Delta(\ln W) / \Delta t$. The model calculations use the measured data on Chl $a$ concentration in Skive Fjord (same authors' Fig. 5, where the missing period from January to June 2011 has been copied from the same period in 2010), as well as data on temperature from 10-Jun-10 to 12-May-11 that were later provided by the authors. These environmental data are shown in Fig. 2.

Starting from the initial condition given by the first data point in Table 2 ( $t_{0}=14-\mathrm{Jul}-10, W_{0}=2$ $\mathrm{mg}$ ) model equations are solved by numerical integration that employs Eq.(7) or (8) (depending on $C<$ or $>C_{\text {sat, }}$, respectively) as long as $W<10.25 \mathrm{mg}$, and then switches to Eqs.(1) or (5), interrupted by use of $\mathrm{d} W / \mathrm{d} t=0$ during the winter period 1 October 2010 to 15 March 2011. This leads to the growth histories $W(t)$ and $L(t)$ in Fig. 3, in which the predictions by the 'standard BEG-model' have been included (dashed curves). Here $L(t)$ is obtained from $W(t)$ by the allometric relation $W(\mathrm{mg})=$ $2.15 \times 10^{-6} L(\mathrm{~mm})^{3.40}$. 
Table 2. Mytilus edulis. Growth data from Nielsen et al. (2016). Time from start of experiment $\left(t-t_{0}, \mathrm{~d}\right)$, shell length $(L, \mathrm{~mm})$, dry weight of soft tissues $(W$, $\mathrm{g})$, and weight-specific growth rate $\left(\mu, \% \mathrm{~d}^{-1}\right)$.

\begin{tabular}{ccccc}
\hline Date & $t-t_{0}(\mathrm{~d})$ & $L(\mathrm{~mm})$ & $W,(\mathrm{~g})$ & $\mu\left(\% \mathrm{~d}^{-1}\right)$ \\
\hline 14-Jul-10 & 0 & 6.2 & 0.002 & \\
3-Aug-10 & 20 & 11.6 & 0.015 & 10.07 \\
1-Sep-10 & 49 & 21 & 0.135 & 7.58 \\
27-Sep-10 & 75 & 27.1 & 0.236 & 2.15 \\
28-Oct-10 & 106 & 30.7 & 0.359 & 1.35 \\
16-Mar-11 & 245 & 30.4 & 0.261 & -0.23 \\
10-May-11 & 300 & 37.2 & 0.547 & 1.35 \\
\hline
\end{tabular}

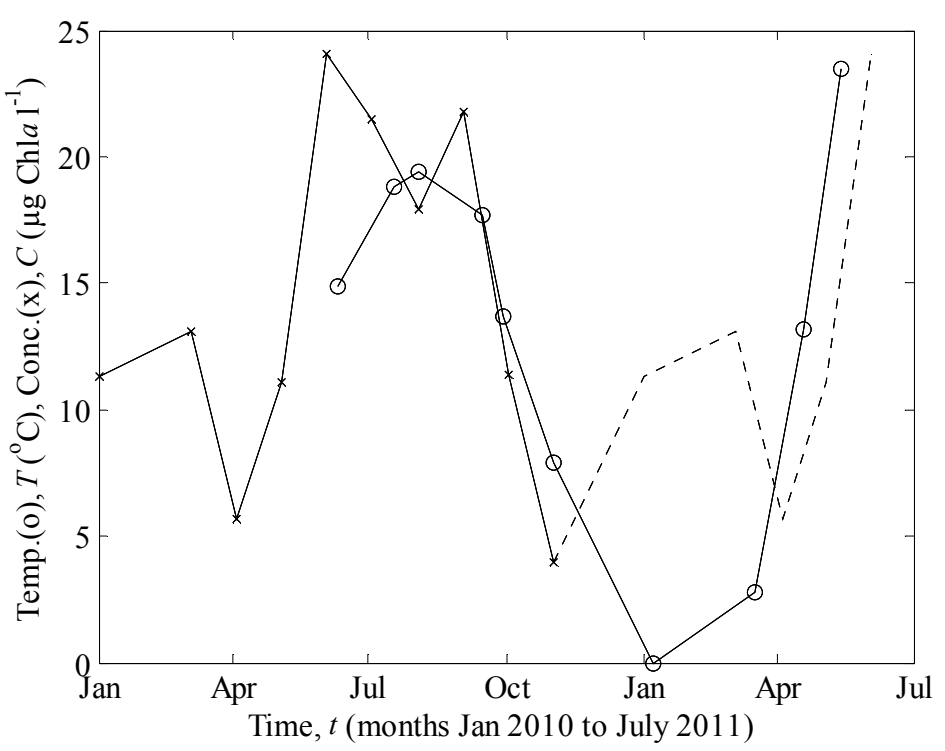

Figure 2. Time series of Chl $a$ concentration $(\times)$ and temperature (o) in Skive Fjord. Data points from Nielsen et al. (2016, with supplementary temperature data provided later by the authors). Chl $a$ data copied from the previous year shown with dotted line. 

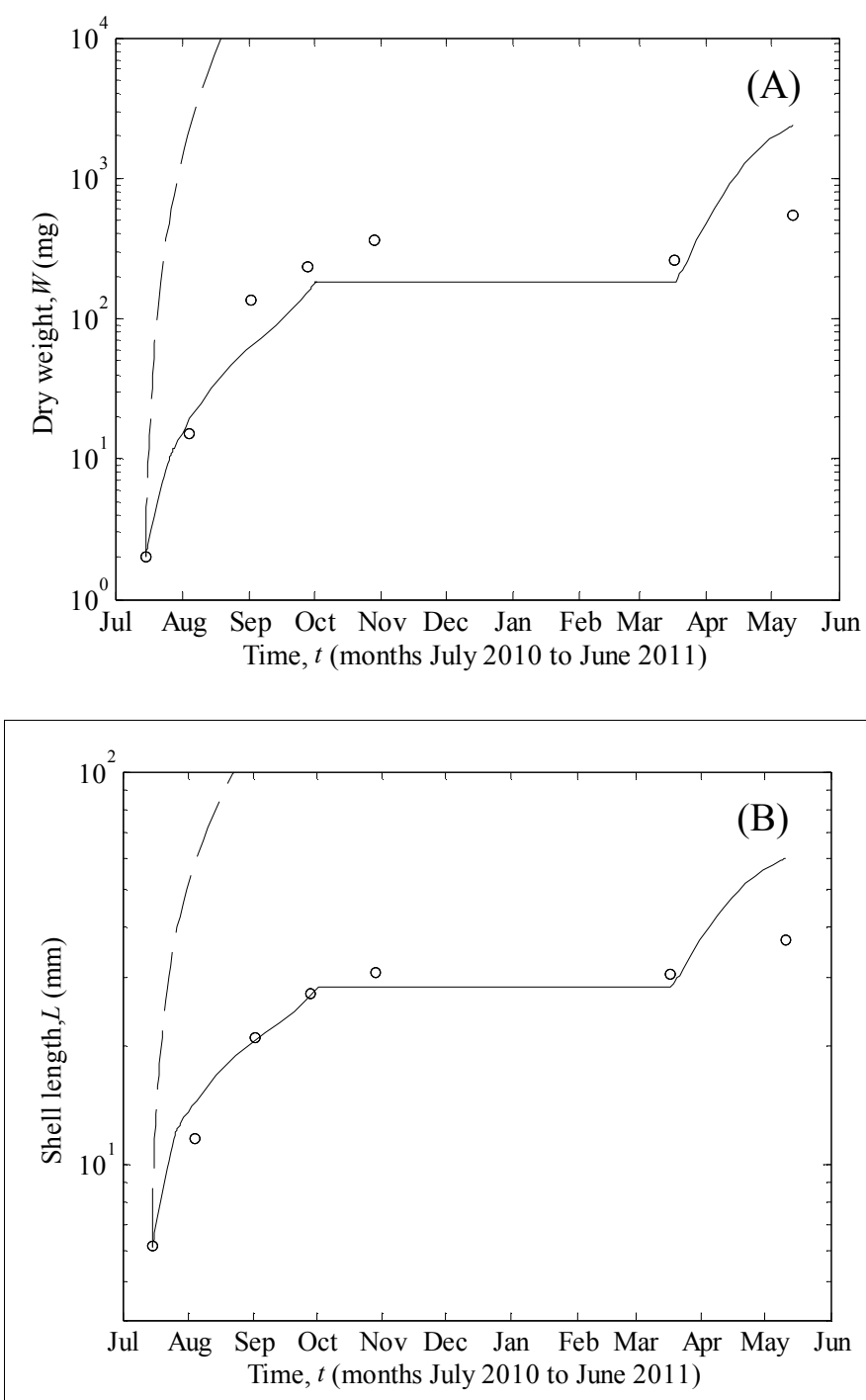

Figure 3. Growth prediction of (A) dry weight of soft tissues, $W(t)$ and corresponding (B) shell length $L(t)$. 'Standard BEG-model' for $A E=0.90$ (dashed), 'high Chl $a$ BEG-model' with ad hoc extension for $W<10.25 \mathrm{mg}$ and $\mathrm{d} W / \mathrm{d} t=0$ during winter period (solid). Data points (o) from Nielsen et al. (2016).

\subsection{Discussion}

The proposed 'high Chl $a$ BEG-model' is based on the experimentally observed decrease in weightspecific growth rate of small (20 to $25 \mathrm{~mm}$ shell length) mussels with increasing Chl $a$ concentration in laboratory and field studies (Fig. 1). Despite the considerable scatter of data this decrease is interpreted as a decrease in assimilation efficiency and modeled by an exponential decrease above the limit $\left(C_{\text {sat }}\right)$ of incipient saturation (Eq.5) which is shown in Fig. 1. Further, the model assumes the rates of filtration and respiration to scale with mussel size $\left(\approx W^{0.66}\right)$ as implied by the 'standard BEG-model' and morphologically justified by the area-to-volume scaling of gills.

The test of the model against the recent data of Nielsen et al. (2016) shown in Fig. 3 indicates relatively good agreement during the first period up to October 2010 and further through the fall and winter period of no growth, but then the increase during spring of 2011 is overestimated 
perhaps because the missing Chl $a$ data during November 2010 to May 2011, that was replaced by data from the previous year, do not match the actual conditions. Here, particularly the low value of $5.70 \mu \mathrm{g}^{-1}$ on 3-Apr-11 gives rise to a high rate of growth. It may also be considered a weakness that the model needs a 'winter-limiter' which may be subject to annual change and difficult to generalize but measured parameters at the site, such as Chl $a$ concentration and temperature, do not appear to determine the no-growth period alone. For comparison Fig. 3 also shows how the prediction by the 'standard BEG-model' grossly overestimates growth rate during the summer.

It is noted that the 'high Chl $a$ BEG-model' may only be applicable to newly settled postmetamorphic and small juvenile (non-spawning) mussels in eutrophicated Danish and other temperate waters. At other localities, e.g. in the stable Californian climate in the Santa Barbara Channel, USA, Page \& Hubbard (1987) found that $20 \mathrm{~mm}$ Mytilus edulis suspended in cages were growing at high rates year around at 12 to $18{ }^{\circ} \mathrm{C}(5$ to $6 \mathrm{~mm}$ shell length per month in January to February and 9 to $10 \mathrm{~mm}$ per month in June) even though Chl $a$ concentrations were relatively low (about 1 and $2.5 \mu \mathrm{g} \mathrm{l}^{-1}$, respectively).

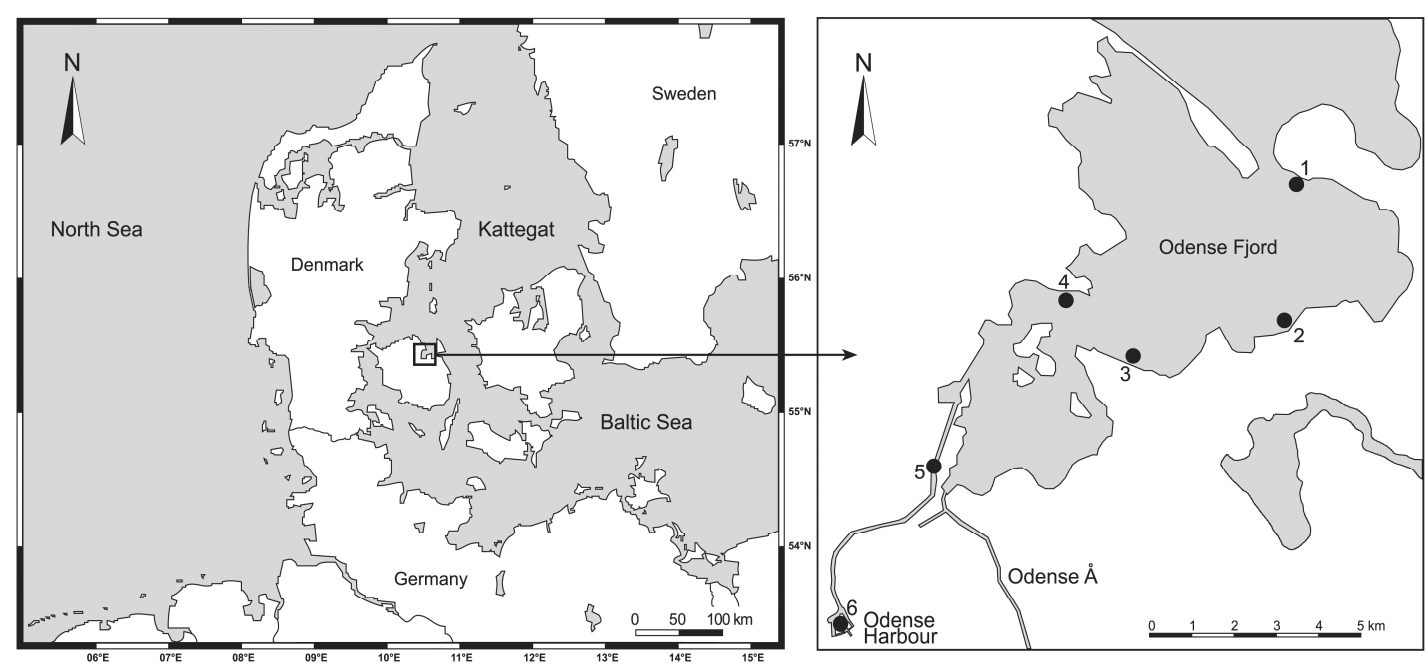

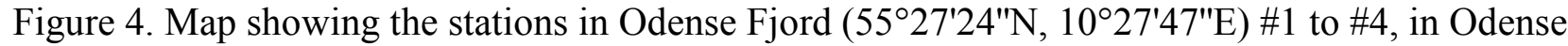

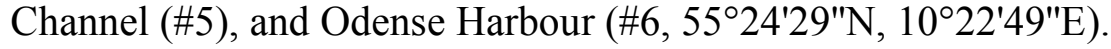

\section{Case study: Growth of Mytilus edulis along $\mathrm{Chl} a$ and salinity gradients in Odense Fjord}

\subsection{Objective}

The aim of the present case study was to measure the weight-specific growth rates of juvenile Mytilus edulis suspended in net bags along suggested opposed Chl $a$ and salinity gradients in a Danish fjord system in order to evaluate the role of increasing food supply versus decreasing salinity for growth.

\subsection{Materials and methods}

Odense Fjord (Denmark, Fig. 4) is rich in nutrients and receives freshwater from a large agricultural catchment area (Riisgård et al. 2008). The surface salinity in the shallow inner part varies during the year between 10 and $15 \mathrm{psu}$, whereas the surface salinity of the outer fjord varies from 16 to $20 \mathrm{psu}$. The $\mathrm{Chl} a$ concentrations on the contrary are highest in the inner fjord $(10.0 \pm$ $9.6 \mu \mathrm{g}^{-1}$ ) and decrease (to $4.3 \pm 0.7 \mu \mathrm{g}^{-1}$ ) along an estuarine gradient towards the adjacent 
Northern Belt Sea (Riisgård et al. 2008, Petersen et al. 2009). Odense Harbour (Fig. 4) is connected via the Odense Channel to the innermost part of Odense Fjord and receives frequently freshwater from over-running rainwater basins. Odense Harbour is eutrophicated and water exchange with the adjacent Odense Fjord takes place through the $7.5 \mathrm{~km}$ long Odense Channel of narrow width between 50 to $90 \mathrm{~m}$. In the present case study the growth rates of Mytilus edulis in net bags were measured at 6 stations (Fig. 4), but two of the stations (\#2 and \#4) have not be included into the analysis due to loss of mussels along the opposed $\mathrm{Chl} a$ and salinity gradients between Odense Harbour and the outer Odense Fjord.

Blue mussels were collected in the inlet to Kerteminde Fjord $\left(55^{\circ} 26^{\prime} 59^{\prime \prime N}, 10^{\circ} 39^{\prime} 41^{\prime \prime} \mathrm{E}\right)$ in June and July 2016, cleaned of epifauna and placed overnight in bio-filtered running seawater. The shell length of mussels to be used in growth experiments was measured by means of a calliper rule and individuals of approximately the same size $\left(L_{0}=22.7 \pm 1.7 \mathrm{~mm}\right.$, mean $\left.\pm \mathrm{SD}\right)$ were selected $(n=$ 390).

Every week temperature, salinity and chlorophyll $a$ concentration were measured using a YSI 650 (Yellowstone Scientific Instruments, Big Sky, Montana, USA, 6 to $12 \%$ uncertainty of Chl $a$ measurements in the used range) at $1 \mathrm{~m}$ depth (and $1 \mathrm{~m}$ away from the harbour wall) at the study sites.

Mussels were transferred to commercially manufactured cylinder-shaped net bags $(n=30)$ made of polypropylene fibres with a mask width of $10 \mathrm{~mm}$. The bags were placed in groups of 3 in stainless steel frames $(40 \times 40 \mathrm{~cm})$ approximately $1 \mathrm{~m}$ below the water surface in Odense Harbour, Odense Channel, and 4 stations in Odense Fjord (cf. Fig. 4). The frames were held in position with a buoy and a concrete anchor at the sea floor. Every 14 days the setup was lifted and one of the net bags containing 30 mussels was taken out carefully. The mussels were brought to the laboratory (Marine Biological Research Centre, Kerteminde) and within $3 \mathrm{~h}$ after collection they were frozen at $-20^{\circ} \mathrm{C}$. Later on shell length $(L, \mathrm{~mm})$ and dry weight of soft parts $(\mathrm{W}, \mathrm{mg})\left(24 \mathrm{~h}, 90^{\circ} \mathrm{C}\right.$, fine balance (Sartorius BP210D)) were determined for representative groups of mussels $(n=30)$ on Day 0 and every second week during a period of 6 weeks. The condition index $\left(C I, \mathrm{mg} \mathrm{cm}^{-3}\right)$ was calculated according to the equation $C I=W / L^{3}$. The weight-specific growth rate $\left(\mu, \% \mathrm{~d}^{-1}\right)$ was determined from the slope of a linear regression line in a semi-ln plot $(b)$ of $\ln W$ versus experimental time $(t, d)$ derived from Eq.(6) in Riisgård et al. 2014 (cf. Fig. S2).

Table 3. Mytilus edulis. Overview of the sampling stations (Fig. 4) and numbers along with initial $\left(L_{0},=22.7 \pm 1.7 \mathrm{~mm}\right)$ and final $\left(L_{\mathrm{t}}\right)$ shell length at time $t$, initial $\left(W_{0}=54.4 \pm 22.6 \mathrm{mg}\right)$ and final dry weight of soft tissues $\left(W_{\mathrm{t}}\right)$, initial $\left(C I_{0}=4.5 \pm 1.2 \mathrm{mg} \mathrm{cm}^{-3}\right)$ and final condition index calculated from $C I=W / L^{3}\left(C I_{\mathrm{t}}\right)$, number of mussels at each harvesting time $(n=5$ to 30$)$, temperature $(T)$, salinity $(S)$, and chlorophyll $a$ concentration $(\mathrm{Chl} a)$ based on weekly measurements $(\Delta t=42 \mathrm{~d}$, growth period between 24 June and 5 August 2016). Data from Fig. S1. Mean \pm SD are indicated.

\begin{tabular}{lccccccc}
\hline$\#$ & Station & $L_{\mathrm{t}}(\mathrm{mm})$ & $W_{\mathrm{t}}(\mathrm{mg})$ & $C I_{\mathrm{t}}\left(\mathrm{mg} \mathrm{cm}^{-3}\right)$ & $S(\mathrm{psu})$ & $\mathrm{Chl} a\left(\mu \mathrm{g} 1^{-1}\right)$ & $T\left({ }^{\circ} \mathrm{C}\right)$ \\
\hline 1 & Gabet & $27.4 \pm 2.4$ & $152.4 \pm 38.1$ & $7.4 \pm 1.4$ & $21.8 \pm 5.1$ & $4.3 \pm 0.7$ & $18.3 \pm 1.2$ \\
3 & Munkebo & $28.8 \pm 1.4$ & $210.9 \pm 57.6$ & $8.7 \pm 1.7$ & $19.0 \pm 3.0$ & $6.2 \pm 1.9$ & $18.9 \pm 1.6$ \\
5 & Odense Channel & $31.5 \pm 2.8$ & $291.1 \pm 88.2$ & $9.2 \pm 2.1$ & $23.6 \pm 4.7$ & $8.8 \pm 1.9$ & $19.5 \pm 2.1$ \\
6 & Odense Harbour & $33.1 \pm 3.0$ & $271.5 \pm 57.6$ & $7.7 \pm 2.6$ & $19.1 \pm 7.7$ & $10.0 \pm 9.6$ & $19.5 \pm 1.7$ \\
\hline
\end{tabular}


Table 4. Mytilus edulis. Mean weight-specific and length growth rates $\left(\mu, \% \mathrm{~d}^{-1}\right.$ and $\left.\mu_{\mathrm{L}}, \mathrm{mm} \mathrm{mo}^{-1}\right)$ derived from slopes of linear regression lines (Figs. S2 and S3 and Table S.2).

\begin{tabular}{cccc}
\hline$\#$ & Station & $\mu\left(\% \mathrm{~d}^{-1}\right)$ & $\mu_{\mathrm{L}}\left(\mathrm{mm} \mathrm{mo}^{-1}\right)$ \\
\hline 1 & Gabet & 2.6 & 3.5 \\
3 & Munkebo & 3.4 & 5.0 \\
5 & Odense Channel & 3.9 & 6.5 \\
6 & Odense Harbour & 4.0 & 7.6 \\
\hline
\end{tabular}
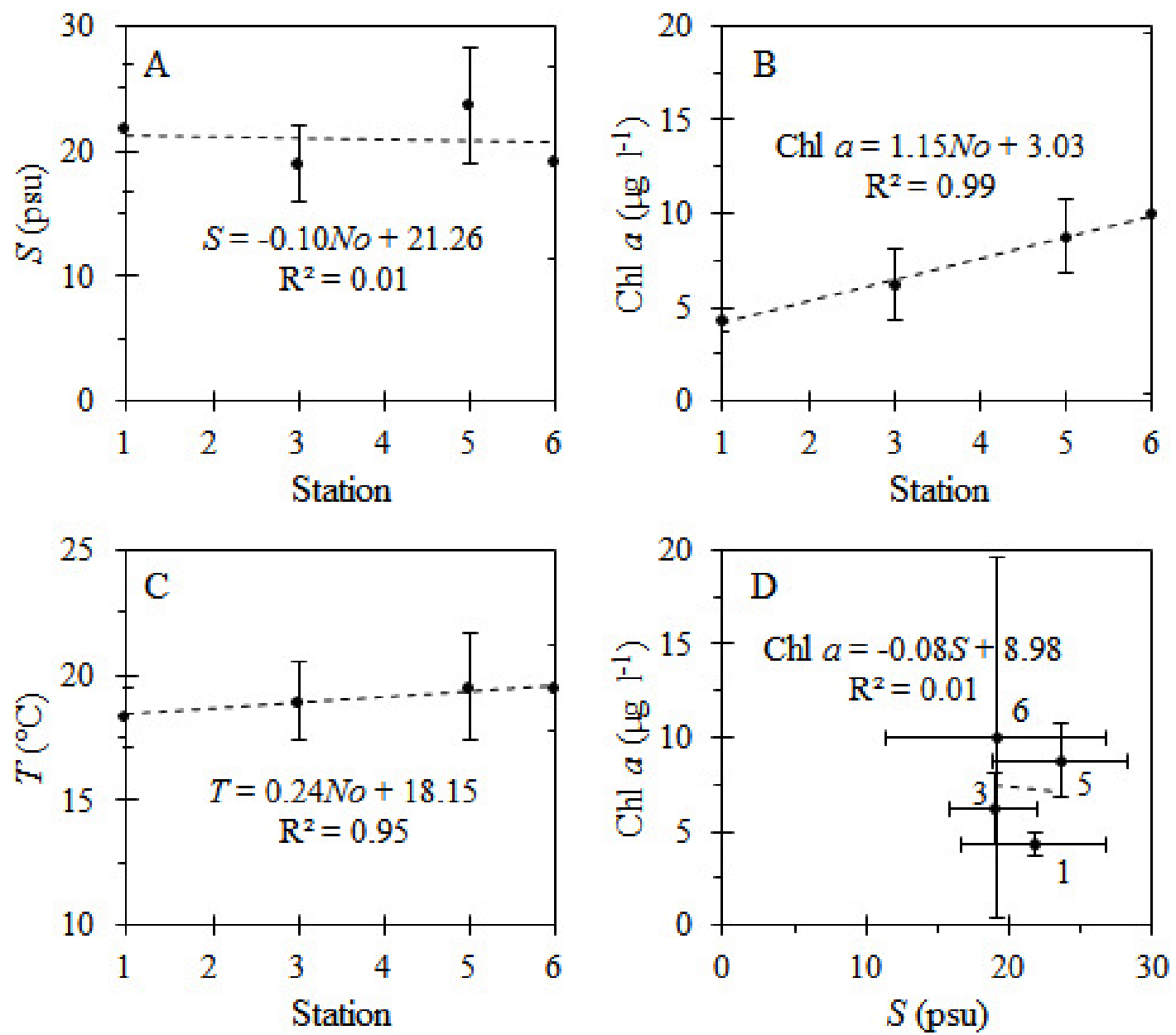

Figure 5. A: Salinity ( $S$, psu), B: chlorophyll $a$ concentration (Chl $\left.a, \mu g 1^{-1}\right)$, and C: temperature $\left(T,{ }^{\circ} \mathrm{C}\right)$ depicted for each sampling station. D: Chl $a$ shown as a function of salinity. Data from Table 3. Dashed linear regression lines are inserted to highlight trends. Mean \pm SD are indicated.

\subsection{Results and discussion}

As summarised in Table 3 and Fig. 5 measured concentration of Chl $a$ increased considerably from station 1 to 6 , as expected, while the decrease of salinity and increase of temperature and the dependence of Chl $a$ on salinity appeared to be negligible. Table 4 shows calculated values of weight-specific and length growth-rates $\mu\left(\% \mathrm{~d}^{-1}\right)$ and $\mu_{\mathrm{L}}\left(\mathrm{mm} \mathrm{d}^{-1}\right)$, respectively, and the 
dependence of $\mu$ on salinity $(S), \mathrm{Chl} a$ concentration $(C)$, temperature $(T)$ and station number is shown in Fig. 6. In principle, the weight-specific growth could depend on at least 3 variables, $\mu=$ $\mu(C, S, T)$, and data from 4 data points in $C, S, T$-space cannot resolve the dependence of any one of the parameters separately because that would require the two other parameters to be kept constant. But the Pearson correlation coefficients: $[\mu, C]=0.967,[\mu, S]=-0.103$ and $[\mu, T]=0.993$ support the foregoing conclusion when noting the very small variations of salinity and temperature. Here it may be noted that our modified BEG-model which accounts for temperature changes (tested in Larsen et al. 2014) predicts a negligible $0.7 \%$ change in $\mu$ for $1{ }^{\circ} \mathrm{C}$ change in temperature at typical conditions below $C \sim 8 \mu \mathrm{g} \mathrm{l}^{-1} \mathrm{Chl} a$, while the sensitivity of $\mu$ to changes in salinity may be estimated to be about 4\% per salinity unit (psu) according to the modified DEB model trend (Maar et al. 2015, Fig.3A therein). Linear regression shows systematic change of $T, S, C$ and $\mu$ during the study to be $1.3^{\circ} \mathrm{C},-0.6 \mathrm{psu}, 5.8 \mu \mathrm{g} \mathrm{l}^{-1}$ and $1.4 \% \mathrm{~d}^{-1}$, respectively, hence $T$ and $S$ could contribute by $1.3 \times 0.7=$ $0.9 \%$ and $-0.6 \times 4=-2.4 \%$, respectively, to the observed change in $\mu$ of $100 \times 1.4 / 3.4=41.2 \%$, while $C$ contributes the rest. These estimates apparently suggest that observed changes in temperature and
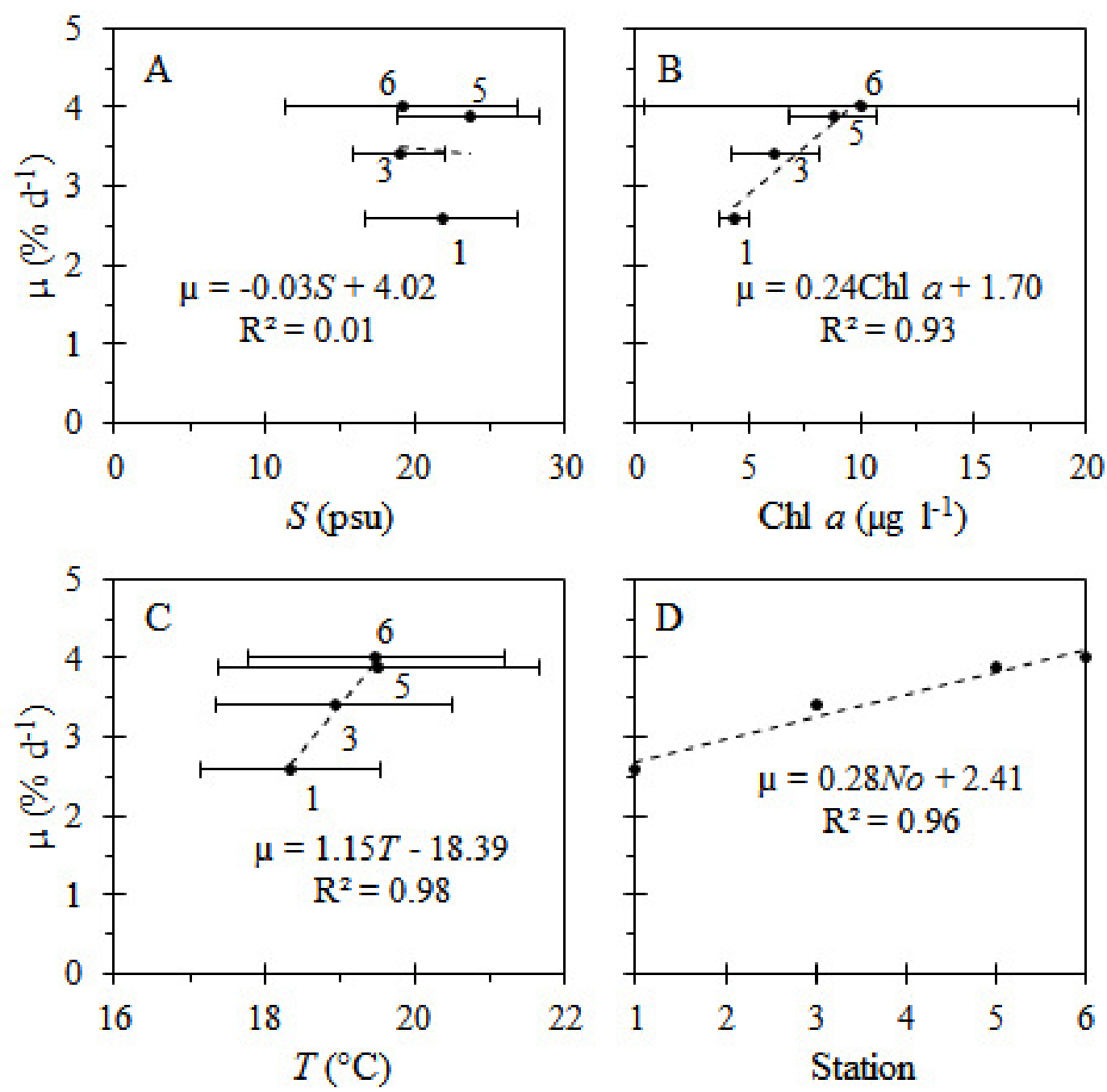

Figure 6. Mytilus edulis. Weight-specific growth rate as a function of A: salinity ( $S$, psu), B: chlorophyll $a$ concentration $\left(\mathrm{Chl} a, \mu \mathrm{g} 1^{-1}\right)$, C: temperature $\left({ }^{\circ} \mathrm{C}\right)$, and $\mathrm{D}$ : station number. Data from 
Tables 3 and 4. Dashed linear regression lines are inserted to highlight trends. Mean \pm SD are indicated.

salinity may be ignored so that $\mu$ can be considered to depend essentially only on Chl $a$ concentration. Of other correlation coefficients, $[S, C]=-0.083$ shows an expected negative but apparently negligible correlation, while the supposedly unrelated parameter sets $[S, T]=0.004$ and $[C, T]=0.974$ are negligible and fortuitously high, respectively. Therefore, the Odense Fjord case study does not provide any information on the effect of changing salinity contrary to expectations. Growth conditions expressed as increase in condition index were quite similar at the 4 stations (cf. Fig. S1C). The problem of separating the effects of several environmental parameters was also faced by Bergström \& Lindegarth (2016) who considered 6 parameters (temperature, salinity, Chl $a$, oxygen, exposure, and latitude) in the study of mussel growth along the west coast of Sweden. The success of data correlation appears to be due to large available data sets, use of elaborate statistical tools, and fitting simple models to localized subsets of data.

Comparing the data of $\mu$ versus $\mathrm{Chl} a$ concentration of Fig. 6B to those of Fig. 1 (that are of the same order of magnitude) shows that the first two low Chl $a$ data (from Odense Fjord) fall close to the prediction of the linear 'standard BEG-model' but that the following two data (close to the harbour) fall well below, implying reduced growth due to the increased $\mathrm{Chl} a$ concentration. Yet, the positive correlation $[\mu, C]=0.967$ suggests the expected trend for values of Chl $a<$ about $8 \mu \mathrm{g} \mathrm{l}^{-}$ ${ }^{1}$ in Fig. 1 . The same trend was found in a pilot study in Odense Harbour in 2015 which showed that the growth conditions of Mytilus edulis in net bags at 3 stations were nearly identical, with weightspecific growth rates of 2.8 to $3.3 \% \mathrm{~d}^{-1}$ at high Chl $a$ of 8.0 to $10.9 \mu \mathrm{g} \mathrm{l}^{-1}$ (cf. Table S1).

\section{Discussion of other data}

In a recent study by Landes et al. (2015) juvenile Mytilus edulis were collected at 6 different localities in Denmark, sorted according to shell length into two size groups ('small ${ }^{\circ}=19.1 \mathrm{~mm}$ shell length and 'big' $=25.3 \mathrm{~mm}$ ) and subsequently transferred to net bags and deployed in the water column for 29 to $50 \mathrm{~d}$. Mussels from start and final samples were measured for dry weight of soft parts $(W, \mathrm{mg})$ and the specific growth rate calculated as: $\mu\left(\% \mathrm{~d}^{-1}\right)=\ln \left(W_{\mathrm{t}} / W_{0}\right) / t \times 100$, where $W_{0}$ and $W_{\mathrm{t}}$ is the dry weight at time $=0$ and time $=t$, respectively. During the growth period, the salinity and concentration of Chl $a$ were recorded. Further, in another recent study by Maar et al. (2015) the same data for 'small' mussels were used, although with some discrepancies (see updated Table 5 communicated by the authors). The two papers which have not mutually cited each other arrive at slightly different conclusions. Landes et al. (2015) reported that 'lower growth rates were found in association with low average salinity' and that the 'greatest growth rates ' were measured at an average of 25.7 and $29.5 \mathrm{psu}$, and further, that 'a decline in growth was recorded at the greatest average salinity (29.9 psu), likely because of differences in local food concentrations'. Maar et al. (2015) compared the actually observed specific growth rates with estimated values using the 'standard DEB model' and found that the model estimated the growth rate in agreement with data for stations with salinities $>25$ psu whereas growth rates 'were overestimated by the DEB model for stations with lower salinities'. But because the measured specific growth rates at stations with different salinities were not directly comparable due to varying Chl $a$ concentrations and temperatures Maar et al. (2015) used a 'modified DEB model' which 'showed a positive linear relationship with increasing salinity up to $25 \mathrm{psu}$, where it stabilised'. In the present study, we suggest an alternative interpretation, namely that high $\mathrm{Chl} a$ and not low salinities have caused the observed reduced growth. Thus from Fig. 1 it appears that the specific growth rates reported by Landes et al. (2015) and Maar et al. (2015) fit into the general pattern of reduced growth above about $8 \mu \mathrm{g} \mathrm{Chl} a 1^{-1}$. Further, Nielsen et al. (2016) estimated that the filtration rate of M. edulis in 
the eutrophic Skive Fjord on 1 September 2010 and 10 May 2011, when the Chl $a$ concentrations were about 10 and $8 \mu \mathrm{g} \mathrm{l}^{-1}$, respectively, were ' 40 to $74 \%$ lower than published values which is in agreement with the present 'high $\mathrm{Chl} a$ BEG-model ${ }^{6}$ where reduced filtration rate is a prerequisite.

Without recourse to models, considering just the Pearson correlation coefficients $[\mu, C]=-0.794$, $[\mu, S]=0.792$ for big mussels, or $[\mu, C]=-0.456,[\mu, S]=0.475$ for small mussels in Table 5 , it appears that either or both hypotheses are supported. However, the reduction in filtration rate at high food concentrations has been widely studied in mussels, cf. outline by Filgueira et al. (2009) who found that the filtration rate in Mytilus galloprovincialis becomes strongly reduced at extremely high $\mathrm{Chl} a$ concentrations, dependent on exposure time, though there was 'no general consensus explaining this', nor if the growth could be affected. Furthermore, the ability of blue mussels to grow within the Baltic Sea Mytilus edulis $\times M$. trossulus hybrid zone which includes the inner Danish waters has recently been studied by Riisgård et al. (2014). It was found that the growth rates of $M$. trossulus and M. edulis in suspended net-bags in the Great Belt (22 psu) were of the same order of magnitude (5.6 and $6.8 \% \mathrm{~d}^{-1}$, respectively) and a trend line in a plot of all available growth data for both mussel species as a function of salinity (see Fig. 7 in Riisgård et al. 2014) indicates that the growth of mussels is 'steadily hampered by reduced salinities from $30 \mathrm{psu}$ down to about $10 \mathrm{psu}$, below which the growth is rapidly reduced to become negative below 4.5 $\mathrm{psu}^{\prime}$. But it may be noted that the decrease of $\mu$ with decreasing salinity above about $10 \mathrm{psu}$ in Fig.3A of Maar et al. (2015) is much steeper than that in Fig.7 of Riisgård et al. (2014), suggesting that salinity is not the only - or even the most - responsible parameter above about $10 \mathrm{psu}$. The data of Table 5 are above 10 psu where the effect of growth reduction is apparently moderate. The present study therefore favors the hypothesis that very high $\mathrm{Chl} a$ concentrations cause reduced growth rate in mussels because they become overloaded with food that they are not evolutionary adapted to utilize. All of these observations underline the difficulties of separating the effect of salinity from the effect of $\mathrm{Chl} a$, hence calls for controlled isothermal experiments in which salinity or Chl $a$ is changed significantly while the other parameter is kept constant.

Table 5. Mytilus edulis. Weight-specific growth rate $\left(\% \mathrm{~d}^{-1}\right)$ of mussels in net bags suspended at 6 Danish localities (St., Landes et al. (2015) or Maar et al. (2015), Fig. 1 therein) during various growth periods (days), mean salinity (psu) and exposed to various mean chlorophyll $a\left(\mathrm{Chl} a, \mu \mathrm{g}^{-1}\right.$ ) concentrations ('small' $=19.1 \mathrm{~mm}$ shell length; 'big' $=25.3 \mathrm{~mm}$ ).

\begin{tabular}{|c|c|c|c|c|c|c|c|c|c|}
\hline \multirow[b]{2}{*}{ Locality } & \multirow[b]{2}{*}{ St. } & \multirow[b]{2}{*}{ days } & \multicolumn{4}{|c|}{ Landes et al. (2015) } & \multicolumn{3}{|c|}{ Maar et al. (2015) } \\
\hline & & & psu & Chl $a$ & $\begin{array}{l}\% \mathrm{~d}^{-1} \\
\mathrm{big}\end{array}$ & $\begin{array}{l}\% \mathrm{~d}^{-1} \\
\text { small }\end{array}$ & psu & Chl $a$ & $\begin{array}{l}\% \mathrm{~d}^{-1} \\
\text { small }\end{array}$ \\
\hline Præstø & 1 & 30 & 10.0 & 10.0 & - & - & 8.5 & 10.4 & 2.4 \\
\hline Nørrefjord & 2 & 50 & 16.1 & 17.2 & 3.3 & 3.8 & 16.1 & 17.2 & 3.7 \\
\hline Lovns & 3 & 29 & 20.5 & 47.3 & 2.9 & 3.8 & 20.5 & 47.3 & 3.9 \\
\hline Skive & 4 & 29 & 25.7 & 13.1 & 5.0 & 5.9 & 25.7 & 13.1 & 5.9 \\
\hline Sallingsund & 5 & 30 & 29.5 & 3.6 & 5.5 & 5.6 & 29.5 & 3.6 & 5.5 \\
\hline Oddesund & 6 & 34 & 29.9 & 6.3 & 4.3 & 3.8 & 29.9 & 6.3 & 4.5 \\
\hline
\end{tabular}

\section{Acknowledgements}

Thanks to Odense Kommune for support of pilot project, Mads Anker van Deurs for productive collaboration and Baojun Tang, Camille S. Gros, Sébastien Delaunay, Clémentine Prat and Thibault Neveu for technical assistance, the harbour masters of Munkebo, Gabet and Bregnør for 
permissions, and Bernd Lüskow for drawing the map. We appreciate the comments to the submitted manuscript made by 3 anonymous reviewers.

\section{References}

Bergström P, Lindegarth M (2016) Environmental influence on mussel (Mytilus edulis) growth - A quantile regression approach. Estuar Coast Shelf S 171:123-132

Clausen I, Riisgård HU (1996) Growth, filtration and respiration in the mussel Mytilus edulis: No regulation of the filter-pump to nutritional needs. Mar Ecol Prog Ser 141:37-45

Dare PJ, Edwards DB (1975) Seasonal changes in flesh weight and biochemical composition of mussels (Mytilus edulis L.) in Conway estuary, North Wales. J Exp Mar Biol Ecol 18:89-97

Dare PJ (1976) Settlement, growth and reproduction of the mussel Mytilus edulis L., in Morecambe Bay, England. Fish Invest Ser II 28:1-25

Famme P (1980) Effect of shell valve closure by the mussel Mytilus edulis L. on the rate of oxygen consumption in declining oxygen tension. Comp Biochem Physiol A Physiol 67:167-170

Famme P, Kofoed LH (1980) The ventilatory current and ctenidial function related to oxygen uptake in declining oxygen tension by the mussel Mytilus edulis L. Comp Biochem Physiol A Physiol 66:161-171

Filgueira R, Fernández-Reiriz MJ, Labarta U (2009) Clearance rate of the mussel Mytilus galloprovincialis. I. Response to extreme chlorophyll ranges. Cienc Mar 35(4):405-417

Gosling E (2015) Marine Bivalve Molluscs, 2nd Edition. Wiley-Blackwell. John Wiley \& Sons, Ltd, West Sussex, UK, pp 524

Jørgensen CB (1966) Biology of suspension feeding. Pergamon Press, Oxford, UK. pp 358

Jørgensen CB (1975) On gill function in the mussel Mytilus edulis L. Ophelia 13:187-232

Jørgensen CB (1990) Bivalve filter feeding: hydrodynamics, bioenergetics, physiology and ecology. Olsen \& Olsen, Fredensborg, Denmark. pp140

Jørgensen CB, Møhlenberg F, Sten-Knudsen O (1986) Nature of relation between ventilation and oxygen consumption in filter feeders. Mar Ecol Prog Ser 29:73-88

Landes A, Dolmer P, Poulsen LK, Petersen JK, Vismann B (2015) Growth and Respiration in Blue Mussels (Mytilus spp.) from Different Salinity Regimes. J Shellfish Res 34:373-382

Larsen PS, Lundgreen K, Riisgård HU (2013) Bioenergetic model predictions of actual growth and allometric transitions during ontogeny of juvenile blue mussels Mytilus edulis, in: Nowak, J., Kozlowski, M. (Eds.), Mussels: Ecology, Life Habits and Control Nova Science Publishers, Inc. New York, USA, pp 101-122 
Larsen PS, Filgueira R, Riisgård HU (2014) Somatic growth of mussels Mytilus edulis in field studies compared to predictions using BEG, DEB, and SFG models. J Sea Res 88:100-108

Larsen PS, Riisgård HU (2016) Growth-prediction model for blue mussels (Mytilus edulis) on future optimally thinned farm-ropes in Great Belt (Denmark). J Mar Sci Eng 4(3),42-55

Maar M, Saurel C, Landes A, Dolmer P, Petersen JK (2015) Growth potential of blue mussels (M. edulis) exposed to different salinities evaluated by a Dynamic Energy Budget model. J Mar Syst $148: 48-55$

Nielsen P, Cranford PJ, Maar M, Petersen JK (2016) Magnitude, spatial scale and optimization of ecosystem services from a nutrient extraction mussel farm in the eutrophic Skive Fjord, Denmark. Aquacult Environ Interact 8:311-329

Page HM, Hubbard DM (1987) Temporal and spatial patterns of growth in mussels Mytilus edulis on an offshore platform: relationships to water temperature and food availability. J Exp Mar Biol Ecol 111:159-179

Pascoe PL, Parry HE, Hawkins AJS (2009) Observations on the measurement and interpretation of clearance rate variations in suspension-feeding bivalve shellfish. Aquat Biol 6:181-190

Petersen JD, Rask N, Madsen HB, Jørgensen OT, Petersen SE, Koch Nielsen SV, Pedersen CB, Jensen MH (2009) Odense pilot river basin: implementations of the EU water framework directive in a shallow eutrophic estuary (Odense Fjord, Denmark) and its upstream catchment. Hydrobiologia 629:71-89

Riisgård HU (2001) Physiological regulation versus autonomous filtration in filter-feeding bivalves: starting points for progress. Ophelia 54:193-209

Riisgård HU, Larsen PS (1995) Filter-feeding in marine macroinvertebrates: pump characteristics, modelling and energy cost. Biol Rev 70:67-106

Riisgård HU, Larsen PS (2015) Physiologically regulated valve-closure makes mussels long-term starvation survivors: test of hypothesis. J Molluscan Stud 81:303-307

Riisgård HU, Jensen MH, Rask N (2008) Odense Fjord and Kerteminde Fjord/Kertinge Nor. Ecology of the Baltic Coastal Waters. Chapter 16. Ecol Stud 197:361-394

Riisgård HU, Egede PP, Saavedra IB (2011) Feeding behaviour of mussels, Mytilus edulis, with a mini-review of current knowledge. J Mar Res DOI:10.1155/2011/312459

Riisgård HU, Bøttiger L, Pleissner D (2012) Effect of salinity on growth of mussels, Mytilus edulis, with special reference to Great Belt (Denmark). Open J Mar Sci 2:167-176

Riisgård HU, Pleissner D, Lundgreen K, Larsen PS (2013) Growth of mussels Mytilus edulis at algal (Rhodomonas salina) concentrations below and above saturation levels for reduced filtration rate. Mar Biol Res 9:1005-1017 
Riisgård HU, Larsen PS, Turja R, Lundgreen K (2014) Dwarfism of mussels in the low saline Baltic Sea - growth to the salinity limit. Mar Ecol Prog Ser 517:181-192

Tang B, Riisgård HU (2016) Physiological regulation of valve-opening degree enables mussels Mytilus edulis to overcome starvation periods by reducing the oxygen uptake. Open J Mar Sci 6:341-352 
SUPPLEMENTARY MATERIAL
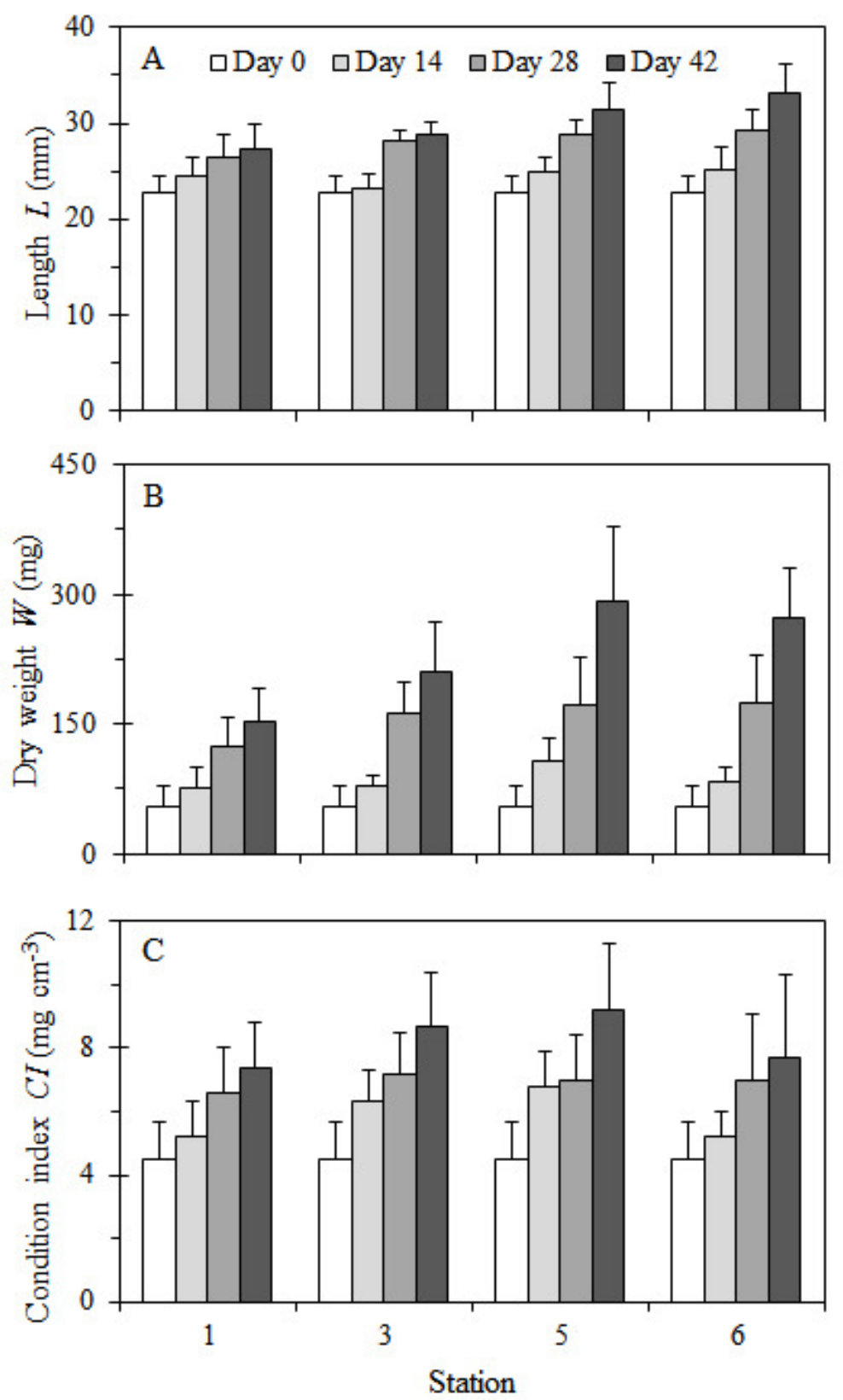

Figure S1. Mytilus edulis. (A): Shell length $(L, \mathrm{~mm}),(\mathrm{B})$ dry weight of soft tissues $(D W, \mathrm{mg})$, and (C) condition index $\left(C I, \mathrm{mg} \mathrm{cm}^{-3}\right)$ measured over 42 days at 4 times (Day 0, 14, 28, and 42) split up per station $(n=5-30)$. Mean $\pm \mathrm{SD}$ are indicated. 


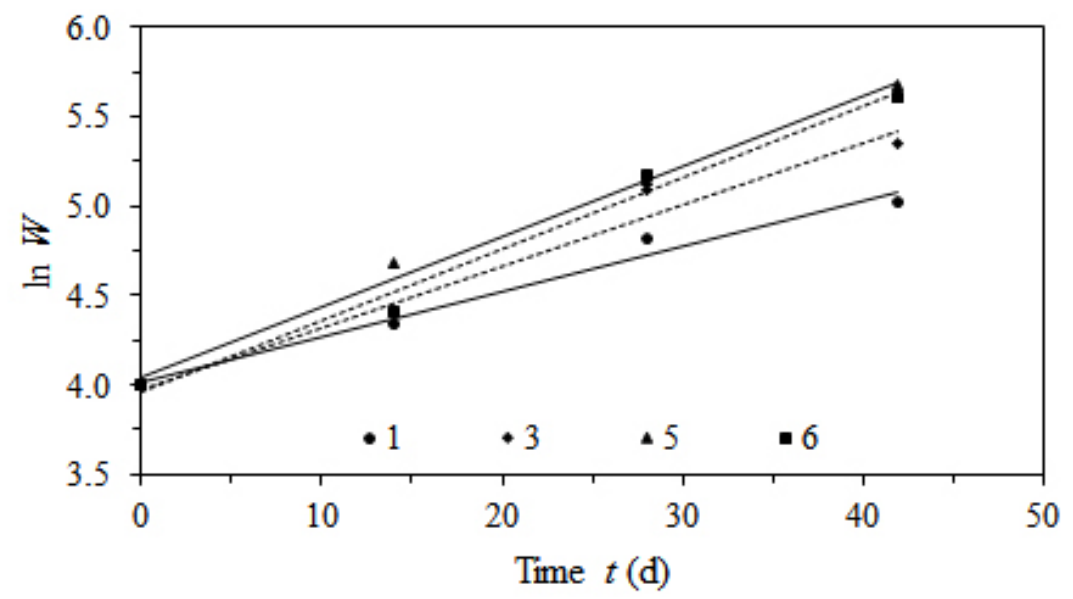

Figure S2. Mytilus edulis. Natural logarithm (ln) of mean dry weight of soft tissues $(W, \mathrm{mg})$ as a function of time $(t, \mathrm{~d})$ at stations $\# 1, \# 3, \# 5$, and $\# 6$. The slope $\mu\left(\% \mathrm{~d}^{-1}\right)$ denotes the weight-specific growth rate over the period and is shown in Table S2.

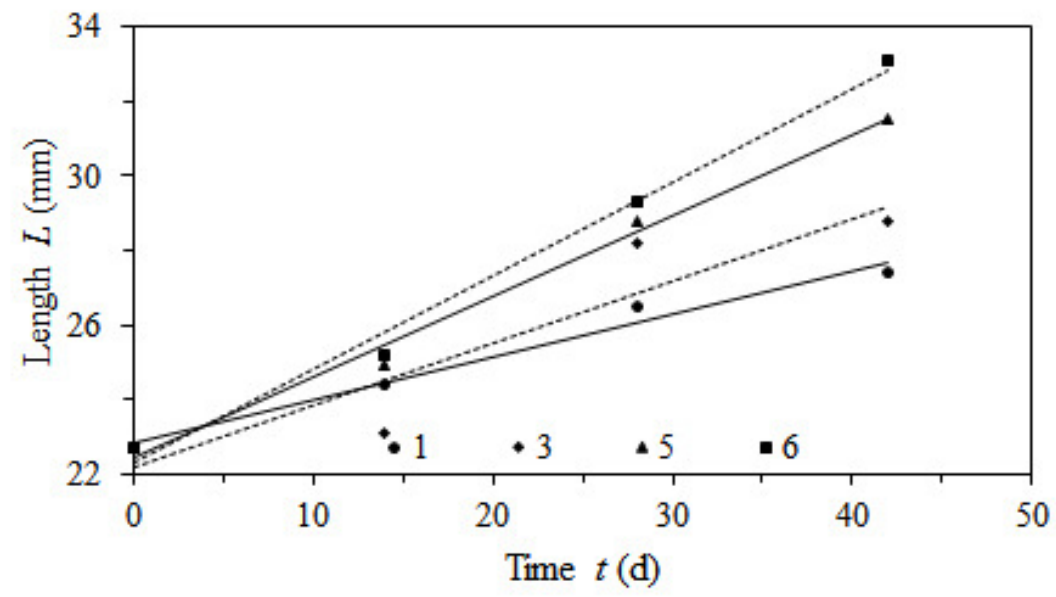

Figure S3. Mytilus edulis. Mean shell length $(L, \mathrm{~mm})$ as a function of time (days) at Station 1, 3, 5 and 6 (Fig. 4). The slope $\mu_{L}\left(\mathrm{~mm} \mathrm{mo}^{-1}\right)$ denotes the length-growth rate over the period and is shown in Table S2. 
Table S1. Mytilus edulis. Overview of the sampling stations in Odense Harbour along with initial $\left(L_{0}, \mathrm{~mm}\right)$ and final $\left(L_{\mathrm{t}}, \mathrm{mm}\right)$ shell length at time $t$, number of replicates $(n=24$ to 30$)$, temperature $\left(T=14.1\right.$ to $\left.20.6{ }^{\circ} \mathrm{C}\right)$, salinity $(S, \mathrm{psu})$, and chlorophyll $a$ concentration $\left(\mathrm{Chl} a, \mu \mathrm{g}{ }^{-1}\right)$ based on weekly measurements ( 8 June to 21 July 2015 ), weight-specific growth rate $\left(\mu, \% \mathrm{~d}^{-1}\right)$, and lengthgrowth rate $\left(\mu_{\mathrm{L}}, \mathrm{mm} \mathrm{mo}^{-1}\right)$. Mean $\pm \mathrm{SD}$ are indicated.

\begin{tabular}{cccccccc}
\hline Station & $\Delta t$ & $L_{0}(\mathrm{~mm})$ & $L_{\mathrm{t}}(\mathrm{mm})$ & $S(\mathrm{psu})$ & $\mathrm{Chl} a\left(\mu \mathrm{g} \mathrm{l}^{-1}\right)$ & $\mu\left(\% \mathrm{~d}^{-1}\right)$ & $\mu_{\mathrm{L}}\left(\mathrm{mm} \mathrm{mo}^{-1}\right)$ \\
\hline 1 & 42 & $22.5 \pm 1.6$ & $31.5 \pm 2.9$ & $17.7 \pm 1.3$ & $10.4 \pm 6.3$ & 3.3 & 6.4 \\
2 & 42 & $22.5 \pm 1.6$ & $31.4 \pm 2.7$ & $17.1 \pm 2.4$ & $8.0 \pm 3.8$ & 2.8 & 6.5 \\
3 & 42 & $22.5 \pm 1.6$ & $31.8 \pm 2.2$ & $16.4 \pm 3.1$ & $10.9 \pm 5.1$ & 3.0 & 6.6 \\
\hline
\end{tabular}

Table S.2. Mytilus edulis. Equations of dry weight of soft parts (Eq.1) and shell length (Eq.2) development of mussels per station (data from Figs. S2 and S3) along with their $\mathrm{R}^{2}$ and weightspecific and length growth rates $\left(\mu, \% \mathrm{~d}^{-1}\right.$ and $\left.\mu_{\mathrm{L}}, \mathrm{mm} \mathrm{mo}^{-1}\right)$ derived from slopes of linear regression lines.

\begin{tabular}{lccccccc}
\hline$\#$ & Station & Eq.1 & $\mathrm{R}^{2}$ & $\mu\left(\% \mathrm{~d}^{-1}\right)$ & Eq.2 & $\mathrm{R}^{2}$ & $\mu_{\mathrm{L}}\left(\mathrm{mm} \mathrm{mo}^{-1}\right)$ \\
\hline 1 & Gabet & $\ln W=0.0255 t+4.0088$ & 0.982 & 2.6 & $L=0.1157 t+22.82$ & 0.978 & 3.5 \\
3 & Munkebo & $\ln W=0.0343 t+3.9753$ & 0.966 & 3.4 & $L=0.1671 t+22.19$ & 0.866 & 5.0 \\
5 & Odense Channel & $\ln W=0.0393 t+4.0471$ & 0.994 & 3.9 & $L=0.2164 t+22.43$ & 0.990 & 6.5 \\
6 & Odense Harbour & $\ln W=0.0399 t+3.9570$ & 0.986 & 4.0 & $L=0.2521 t+22.28$ & 0.990 & 7.6 \\
\hline
\end{tabular}

